\title{
ATTITUDES OF STUDENTS TOWARDS GAMETE DONATION AND BASIC LIFE VALUES
}

\author{
Jelena Opsenica Kostic, Damjana Panic, \& Milica Mitrovic \\ Department of Psychology, Faculty of Philosophy, University of Nis (Serbia)
}

\begin{abstract}
Gamete donation is a procedure that includes the "reproductive others" in the process of conception. There are numerous dilemmas related to donation while various European countries have different ways of solving them. In the Republic of Serbia, only voluntary gamete donation is allowed, and donors can only be women and men from the general population, or women included in the In vitro fertilization process. The donors remain anonymous to the child which was conceived with their help. Overcoming infertility in this way usually includes building public awareness, especially when it is not a common practice in that society, and work should be done on forming positive attitudes towards the donation. Experience from other countries indicates that sperm donation usually does not represent a problem, but there is greater demand for egg cells than the existing supply, which is an additional reason for studying attitudes and planning appropriate campaigns. In this study, the attitudes of university students $(N=503$; 206 young men, 297 young women) towards gamete donation were analyzed, as were the differences in the extent of basic values about acceptance of the donation. We used several questions to determine the attitudes towards donations, including those specially designed for this research and the Schwartz Personal Values Questionnaire (Schwartz, 2002). University students are young people who represent not only potential donors but also the everyday environment of couples who require a donation. As highly educated individuals, they have the potential to be attitude holders. The results have shown generally positive attitudes of the students towards donation. The differences in certain basic values among the participants who support donation were obtained only for the sub-sample of young men: a more pronounced Openness to change and Self-transcendence. The authors present some specific ideas regarding the promotion of gamete donation in general - for example, we believe that in the supporting campaign for donation it would be more appropriate to use Self-transcendence than Openness to change.
\end{abstract}

Keywords: Gamete donation, potential donors, attitudes towards donation, basic life values.

\section{Introduction}

Gamete donation in the Republic of Serbia was made legal by the Law on Biomedically Assisted Fertility from April 2017 (Law on BMAF; Official Gazette of the RS, 40/2017). However, the law is still not being realized in practice - additional regulations were passed in 2019, but there are still many unresolved issues in practice. The obstacles were not removed in 2020, a year that has placed the health system under significant pressure due to the pandemic caused by COVID-19. The aim of this study is to obtain information that is useful in the process of planning the promotion of voluntary gamete donation, as provided by law.

\subsection{Gamete donation}

Gamete donation - the donation of sperm and egg cells - for the purpose of overcoming infertility is a 'third party' fertility treatment (ESHRE fact sheets 3, 2017), that is, one that includes 'reproductive others' (Freeman, Graham, Ebtehaj, \& Richards, 2014), as is the case with embryo donation and surrogate motherhood. The European IVF-monitoring Consortium (EIM) has published a summary of the data related to assisted human reproduction in European countries, based on the data obtained in December 2018 (Calhaz-Jorge et al., 2020). The data indicate that the use of donated gametes is allowed in most countries. However, many countries have reported that they do not have local donors. Even though the report has (accurately) showed what is allowed in the Republic of Serbia and to whom (Calhaz-Jorge et al., 2020), these data refer only to the options that the law makes provisions for - as stated at the beginning, the law is still not in effect. At the same time, the law only makes provisions for 
voluntary gamete donation, while donors can be both women and men from the general population or women included in the In vitro fertilization process. The donors remain anonymous to the child conceived with their help.

\subsection{Attitudes and motives related to gamete donation}

The social and psychological factors which determine donation are of great importance for fertility clinics, lawmakers, and promotional campaigns. A study carried out in six European countries (France, Germany, Italy, Spain, Sweden, and the UK) indicates that $78 \%$ of the respondents from the general population support egg and sperm donation (Fauser, 2019). The most frequently studied aspect is motivation regarding oocyte donation (ED), which is understandable considering the demand and the complexity of the procedure. Any decision-making process is additionally burdened by the fact that there is more than one type of donor. The basic division is into patient-donors and non-patient ones. Patient-donors are individuals undergoing IVF, who for some reason would like to donate their reproductive cells or unused embryos. Non-patient donors are usually divided by researchers into known, commercial, voluntary, and potential (Purewal \& van den Akker, 2009a). Although many donors have altruistic motivations behind their decision, most would not donate without some monetary compensation (Lee et al., 2017; Kenney \& McGowan, 2010).

In studies which involved voluntary egg donors, the most important motive or basic value that was singled out was altruism (e.g., Byrd, Sidebotham, \& Lieberman, 2002; Kirkman, 2003; Jadva, Freeman, Kramer, \& Golombok 2011; Lampic, Skoog-Svanberg, \& Sydsjö 2014). Research has shown that many voluntary donors have experience with infertility through their family members, friends, or business ties, which motivates them to help others (Bracewell-Milnes et al., 2016; Byrd et al., 2002). It is interesting that most voluntary donors are opposed to financial compensation for oocyte donation (Purewal \& van den Akker, 2009a). When it comes to potential donors, studies have shown that both men and women from the general population display positive attitudes towards ED (e.g., Chliaoutakis, Koukouli, \& Papadakaki, 2002; Isikoglu et al., 2006; Khalili, Isikoglu, \& Ghasemi, 2006; Purewal and van den Akker, 2006, 2009). In some studies it was determined that men have more positive attitudes towards ED than some women (Chliaoutakis et al., 2002; Isikoglu et al., 2006). Despite the positive attitudes of potential donors, the number of donated cells, especially eggs, is still too small. Basic life values, as desirable goals, also have a motivational function in the lives of people - for that reason it would be good to obtain information on the basic values of potential donors, and focus a promotional campaign, among other things, on promoting these values.

\subsection{Objectives}

The basic aim of this study is to analyze student attitudes, as attitudes of potential donors, towards gamete donation, along with any potential differences in basic life values between groups divided based on gender and their attitude towards gamete donation (young men/women who are in favor of it, and those who are undecided and against donation).

\section{Methods}

\subsection{The sample of respondents and the procedure}

The sample of respondents consisted of 503 students of the University of Nis, Serbia, 206 young men and 297 young women (aged from 18 to $27 ; M=20.57, S D=1,41$ ). The study was carried out in various faculties in the spring of 2019. The respondents were informed about the goals of the study and gave their oral consent to participate in the research. They were also provided with the information that they could at any time, without any explanation, choose not to fill out the questionnaire.

\subsection{The instruments}

At the very beginning of the questionnaire, a short text was provided which informed the respondent that the Republic of Serbia has a law which allows the donation of a gamete, since we wanted to be sure that the respondents understood that we were asking them about a real possibility for overcoming infertility in Serbia. After that the respondents first answered the question of whether they had, prior to viewing the questionnaire, been aware of the existence of such a law. What followed was a set of questions regarding whether the respondents support gamete donation, formulated based on the questionnaire on oocyte donation, as well as questions on general attitudes towards donation (Skoog-Svanberg, Lampic, Bergh, \& Lundkvist, 2003). Based on their responses, the respondents were divided into two groups: those who were consistently in favor of this option, and those who were undecided or against donation. 
To measure the basic values we used the Schwartz questionnaire, a form which was designed for ESS research (European Social Survey; Schwartz, 2002). The questionnaire consisted of 21 statements on various goals in life, and the respondents provided answers on a six-level Likert scale, ranging from 1 - completely irrelevant, to 6 - exceptionally important (for the respondent). The analysis of the results used scores which denote four categories of the highest order: Openness to change, Conservation, Self-transcendence, and Self-enhancement.

\section{Results}

Most of the respondents (74,3\% young men and $60,9 \%$ you women) had no knowledge of the Law on BMAF before completing the survey questionnaire. Based on whether they consistently support donation (that it is a good way of assisting couples without children; adoption should/should not be the couple's first choice; supporting a friend as a donor and as a recipient of donated cells), the respondents were divided into two groups. One group included respondents who were consistently in favor of donation, while the other consisted of respondents who were undecided and against donation. The results indicate that $53,4 \%$ of the young men $(\mathrm{N}=110)$ and $73,4 \%$ of the young women $(\mathrm{N}=218)$ consistently support donation; the difference is statistically significant $\left(\chi^{2}=21,45 ; p<.001\right)$. The analyses were carried out for the young men and women separately, since they differ in terms of expressed basic life values: Openness to change $(\mathrm{t}=4.200 ; \mathrm{p}<.001)$, Self-transcendence $(\mathrm{t}=4.511 ; \mathrm{p}<.001)$ and Self-enhancement $(\mathrm{t}=2.574 ; \mathrm{p}=.01)$ were more pronounced among the young women; significant differences were not determined for Conservation.

Table 1. Differences in the extent of basic values in relation to the category of the attitude toward gamete donation among young men (consistently in favor of compared to undecisive and against).

\begin{tabular}{|c|c|c|c|c|c|c|c|}
\hline & \multirow[t]{2}{*}{$\mathrm{t}$} & \multirow[t]{2}{*}{ df } & \multirow[t]{2}{*}{$\mathrm{p}$} & \multirow[t]{2}{*}{$\mathrm{M}$} & \multirow[t]{2}{*}{$\begin{array}{c}\text { SE } \\
\text { difference }\end{array}$} & \multicolumn{2}{|c|}{$\begin{array}{c}95 \% \text { confidence } \\
\text { interval }\end{array}$} \\
\hline & & & & & & Upp. & Low \\
\hline Openness to change & 4,072 & 171,392 & $<.001$ & .55 & .14 & .28 & .82 \\
\hline Conservation & 1,548 & 184,423 & $\mathrm{NS}$ & .18 & .12 & -.05 & .42 \\
\hline Self-transcendence & 4,104 & 182,128 & $<.001$ & .56 & .14 & .29 & .83 \\
\hline Self-enhancement & 1,736 & 204 & NS & .19 & .11 & -.02 & .40 \\
\hline
\end{tabular}

Note. NS - the difference is not statistically significant.

The young men in favor of gamete donation scored higher on Openness to change and Selfenhancement, compared to young men who were undecided or against donation. The differences in Conservation and Self-transcendence were not statistically significant.

Table 2. Differences in the extent of basic values in relation to the category of attitudes toward gamete donation among the young women (consistently in favor of compared to undecisive and against).

\begin{tabular}{|c|c|c|c|c|c|c|c|}
\hline & \multirow[t]{2}{*}{$\mathrm{t}$} & \multirow[t]{2}{*}{$\mathrm{df}$} & \multirow[t]{2}{*}{$\mathrm{p}$} & \multirow[t]{2}{*}{$\mathrm{M}$} & \multirow[t]{2}{*}{$\begin{array}{c}\text { SE } \\
\text { difference }\end{array}$} & \multicolumn{2}{|c|}{$\begin{array}{c}95 \% \text { confidence } \\
\text { interval }\end{array}$} \\
\hline & & & & & & Upp. & Low. \\
\hline Openness to change & ,747 & 109,28 & NS & .07 & .10 & -.12 & .26 \\
\hline Conservation & 880 & 295 & $\mathrm{NS}$ & .08 & .09 & -.10 & .26 \\
\hline Self-transcendence & ,873 & 97,52 & NS & .07 & .08 & -.09 & .24 \\
\hline Self-enhancement & 1,335 & 295 & NS & .12 & .09 & -.06 & .31 \\
\hline
\end{tabular}

Note. NS - the difference is not statistically significant.

In the case of the young women, no statistically significant differences were determined in the extent of the basic values among those who are in favor of donation and those who are undecided or against donation.

\section{Discussion}

The results indicate that most of the respondents were not aware of the Law on BMAF. The enactment of the law was reported in the daily news, but it is clear that these are not the channels that reach young people. The first step in developing positive attitudes towards donation must include an analysis of the media which young people follow, and the choice of suitable means/individuals to convey information. The population of young people is especially important as they represent not only potential donors, but also the environment of the couples in need of a donation. As highly educated individuals 
they have the potential to be attitude holders in their environment, but they must first be given the opportunity to formulate clear opinions based on reliable information.

Considering that our respondents are not familiar with the law, they were not informed about donating, and considering that they had not had the opportunity meet any donors or families that emerged as a result of donation in their environment, none of the components of their attitudes (cognitive, affective, behavioral) could be defined clearly. Still, we resorted to the responses given to several of the questions that refer to their general attitude towards donation (that it is a good way of assisting couples without children; adoption should/should not be the couple's first choice; supporting a friend as a donor and as a recipient of donated cells) in order to divide our respondents into those in favor of donation and those who are unsure or who are against donation. Significantly more young women support donation. The study does not allow us to provide any explanations of these differences in terms of gender; we can assume that the problem of infertility causes greater empathy among young women, and thus leads to greater support for donation on their part, but this hypothesis warrants further analysis. Support for donation is somewhat lower compared to the average results reported in European countries (Calhaz-Jorge et al., 2020), but all these countries have years of practice in gamete donation (with the exception of oocyte donation in Germany, where it is not allowed), so that the increasing number of positive attitudes could be the result of positive experiences with donation.

The basic aim of the study was to analyze the differences in the strength of life values among the respondents who unequivocally support donation and those who are undecided or who are against. In the case of the young men, Openness to change and Self-transcendence were values more pronounced in the group which unequivocally supports gamete donation. Even though it is understandable that young people who believe that it is important to do things your way and try new things in life (Openness to change $=$ Self-direction and Stimulation) support donation, maybe this is not very helpful for the campaign - donation is far from an adventure. The value which can certainly be beneficial is Self-transcendence (Benevolence and Universalism). Thus, in our sample it was confirmed that altruistic values are important for showing support for donation, but only in the case of the young men. Among the young women, none of the differences were statistically significant. In other words, we cannot say that the studied basic values contributed to understanding why some of the young women were in favor of, and some were undecided regarding donation. At the same time, it is interesting that Openness to change and Self-transcendence are actually more pronounced among the young women. We will once again refer to the idea that among the young women more positive attitudes towards donation are shaped more by a specific empathy towards an infertile couple than the general values of universalism and altruism. This should be evaluated in future studies, and, if proven correct, ethically used in the campaign. It is worth mentioning that Conservation (Security, Conformity, and Tradition) is not a basic life value which, for this sample of students, contributes to the differences in attitudes.

In future studies, once donation actually begins in the Republic of Serbia, we should analyze the attitudes towards anonymity and financial compensation for donors, as well as towards the rights of the child to know its origins, that is, analyze the compatibility between the attitudes of the general population, the recipients of donated eggs, and the existing legal acts.

\section{References}

Bracewell-Milnes, T., Saso, S., Bora, S., Ismail, A. M., Al-Memar, M., Hamed, A. H., Abdalla, H., \& Thum, M.Y. (2016). Investigating psychosocial attitudes, motivations and experiences of oocyte donors, recipients and egg sharers: a systematic review. Human Reproduction Update, 22(4), 450-465. doi:10.1093/humupd/dmw006

Byrd, L. M., Sidebotham, M., \& Lieberman B. (2002). Egg donation-the donor's views: an aid to future recruitment. Human Fertility, 5, 175-182.

Calhaz-Jorge, C., De Geyter, C. h, Kupka, M. S., Wyns, C., Mocanu, E., Motrenko, T., Scravelli, G., Smeenk, J., Vidakovic, S. \& Goossens, V. (2020). Survey on ART and IUI: legislation, regulation, funding and registries in European countries. Human Reproduction Open, 2020(1). doi:10.1093/hropen/hoz044

Chliaoutakis, J. E., Koukouli, S., \& Papadakaki, M. (2002). Using attitudinal indicators to explain the public's intention to have recourse to gamete donation and surrogacy. Human Reproduction, 17(11), 2995-3002. doi:10.1093/humrep/17.11.2995

ESHRE fact sheets 3 (2017). Egg donation. Retrieved March 15. 2019. from https://www.eshre.eu/ Press-Room/Resources 
Fauser, B. C. J. M., Boivin, J., Barri, P. N., Tarlatzis, B. C., Schmidt, L., \& Levy-Toledano, R. (2019). Beliefs, attitudes and funding of assisted reproductive technology: Public perception of over 6,000 respondents from 6 European countries. PLOS ONE, 14(1), e0211150. doi:10.1371/journal.pone.0211150

Freeman, T., Graham, S., Ebtehaj, F., \& Richards, M. (2014). Relatedness in Assisted Reproduction. Families, Origins and Identities. Cambridge University Press.

Isikoglu, M., Senol, Y., Berkkanoglu, M., Ozgur, K., Donmez, L., \& Stones-Abbasi, A. (2006). Public opinion regarding oocyte donation in Turkey: fist data from a secular population among the Islamic world. Human Reproduction, 21, 318-323. doi:10.1093/humrep/dei274

Jadva, V., Freeman, T., Kramer, W., \& Golombok, S. (2011). Sperm and oocyte donors' experiences of anonymous donation and subsequent contact with their donor offspring. Human Reproduction, 26, 638-645. doi: 10.1093/humrep/deq364

Kenney, N. J., \& McGowan, M. L. (2010). Looking back: egg donors' retrospective evaluations of their motivations, expectations, and experiences during their first donation cycle. Fertility and Sterility, 93(2), 455-466. doi:10.1016/j.fertnstert.2008.09.081

Khalili, M.A., Isikoglu, M., \& Ghasemi, M. (2006). Attitudes of Christians and Muslims to an oocyte donation program in Iran. Eubios Journal of Asian and International Bioethics 16(3), 66-71.

Lampic, C., Skoog Svanberg, A., Sydsjö, G. (2014). Attitudes towards disclosure and relationship to donor offspring among a national cohort of identity-release oocyte and sperm donors. Human Reproduction, 29, 1978-1986. doi: 10.1093/humrep/deu152

Lee, M. S., Farland, L. V., Missmer, S. A., \& Ginsburg, E. S. (2017). Limitations on the compensation of gamete donors: a public opinion survey. Fertility and Sterility, 107(6), 1355-1363.e4. doi:10.1016/j.fertnstert.2017.03.001

Purewal, S., \& van den Akker OBA. (2006). British women's attitudes towards oocyte donation: ethnic differences and altruism. Patient Education and Counseling, 64, 43-49.

Purewal, S., \& van den Akker, O.B.A. (2009). Systematic review of oocyte donation: investigating attitudes, motivations and experiences. Human Reproduction Update, 15(5), 499-515.

Schwartz, S. H. (2002). A Proposal for Measuring Value Orientations across Nations. https://pdfs.semanticscholar.org/376a/d809f1313cb41dfcffa8bd180949c273f8c2.pdf

Skoog-Svanberg, A., Lampic, C., Bergh, T., \& Lundkvisk, Ö. (2003b). Public opinion regarding oocyte donation in Sweden. Human Reproduction, 18, 1107-1114. doi: 10.1093/humrep/deg222

Zakon o Biomedicinski potpomognutoj oplodnji - Law on Biomedically Assisted Fertility (2017). Available at: http://www.pravno informacioni sistem.rs/SlGlasnikPortal/eli/rep/sgrs/ skupstina/zakon/2017/40/1 